\title{
Lap-Protector and Circular
}

\section{Stapler Are Useful in}

\section{Cystogastrostomy for Large Pancreatic Pseudocyst with Severe Infection}

\author{
Yoshihiko Kadowaki ${ }^{\mathrm{a}, \mathrm{b}}$ Takefumi Kurokawa ${ }^{\mathrm{b}}$ \\ Ryuji Tamura ${ }^{\text {a }}$ Takahiro Okamoto $^{a}$ Nobuhiro Ishido ${ }^{a}$ \\ Takashi Moria \\ aDepartment of Surgery, Kobe Red Cross Hospital, and bHyogo Emergency \\ Medical Center, Kobe, Japan
}

\section{Key Words}

Lap-Protector · Circular stapler · Pancreatic pseudocyst

\begin{abstract}
Lap-Protector, which is an abdominal wall sealing device, is usually used for wound protection from implantation of malignant cells or pyogenic fluid. A circular stapler is a common easy-to-use device for anastomosis of the digestive tract. We report the case of an infected pancreatic pseudocyst which was treated by surgical procedure using these useful devices. A 69-year-old man was followed up in our hospital after severe acute pancreatitis. He had undergone drainage surgeries twice for intractable pancreatic abscess followed by severe acute pancreatitis. He was admitted to our hospital complaining of loss of appetite, hiccups, and high fever. Computed tomography of the abdomen revealed an infected pancreatic pseudocyst which compressed the gastric wall. Internal drainage into the stomach was performed using Lap-Protector and circular stapler. The patient recovered uneventfully. Recently many endoscopic or laparoscopic procedures in cystogastrostomy are reported; however, a conventional open surgical approach is also important. This easy method may be useful for operative cystogastrostomy.
\end{abstract}




\begin{tabular}{|c|c|c|c|}
\hline $\begin{array}{r}\text { Case Reports in } \\
\text { Gastronterolagy }\end{array}$ & $\begin{array}{l}\text { Case Rep Gastroenterol 2010;4:215-219 } \\
\text { DOI: 10.1159/000279763 }\end{array}$ & Published online: July 21, 2010 & \begin{tabular}{|l} 
@ 2010 S. Karger AG, Basel \\
ISSN 1662-0631 \\
www.karger.com/crg
\end{tabular} \\
\hline
\end{tabular}

\section{Introduction}

Lap-Protector was developed as a safe and useful device that may help to prevent infections and cancer cell contamination of minilaparotomy wounds [1]. We applied this device to the gastric anterior wall of the incision in the first step of surgical transgastric cystogastrostomy for a patient with an infected pancreatic pseudocyst. Recently, disposable circular stapler is very popular in digestive organ anastomosis. In 1999, Yunoki et al. reported the advanced use of circular stapler for cystogastrostomy [2]. In this report, we verify the validity of circular stapler in cystogastrostomy.

\section{Case Report}

A 69-year-old man presented to our hospital with a 5-day history of high fever, loss of appetite, and hiccups. Laboratory data on arrival were as follows: white blood cell count, 24,800/ $\mu$ l; C-reactive protein, $13.8 \mathrm{mg} / \mathrm{dl}$. Computed tomography (CT) showed an infected pancreatic pseudocyst which compressed the gastric wall (fig. 1). His past history includes alcohol abuse and severe acute pancreatitis. He had undergone extracorporeal drainage twice before. We made a preoperative diagnosis of the recurrence of infected pancreatic pseudocyst; therefore, emergency operation was performed. According to the Jedlicka's method, transgastric cystogastrostomy was selected [3].

After performing minilaparotomy with upper median incision, a small incision with a length of $3.0 \mathrm{~cm}$ was made on the anterior gastric wall. Placing the Lap-Protector over the incision, the bottom ring is pushed into the lumen of the stomach through the incision. The top and bottom rings of the Lap-Protector formed a sandwich around the anterior gastric wall (fig. 2a). The posterior gastric wall was punctured toward the retrogastric space by a sheath of needle. Thick pus was recognized as expected (fig. 2a). A small incision was made on the posterior wall to reach the abscess wall (fig. 2b). While preventing pollution in the peritoneal cavity, the abscess space was irrigated with saline. Using an Auto Suture PCEEA 25, an anastomosis was approximated between the abscess wall and the posterior gastric wall (fig. 2c-e). Several stitches were added for adequate hemostasis. The anterior gastric wall was closed with layer-to-layer suture.

The patient's postoperative course was uneventful. Four days after the operation, upper gastrointestinal examination and CT using a water-soluble contrast agent showed no anastomotic leakage and complete drainage (fig. 3 ). He was discharged 10 days after the operation. Two months after discharge, follow-up evaluation with upper endoscopy and CT revealed no sign of recurrence (fig. 4).

\section{Conclusions}

A variety of treatments in infectious pancreatic pseudocyst have been reported, such as percutaneous drainage, endoscopic cystogastrostomy, and conventional surgical cystogastrostomy. A less invasive method is likely to be desired. However, we believe that surgical cystogastrostomy still plays an important role in the management of selected cases of pseudocyst of the pancreas. In this case, we performed cystogastrostomy easily without any contamination using Lap-Protector and circular stapler. 


\begin{tabular}{r|l|l|l} 
Case Reports $\boldsymbol{h}$ ( Case Rep Gastroenterol 2010;4:215-219 & Published online: July 21, 2010 & $\begin{array}{l}\text { O 2010 S. Karger AG, Basel } \\
\text { ISSN 1662-0631 } 10.1159 / 000279763 \\
\text { www.karger.com/crg }\end{array}$ \\
\hline
\end{tabular}

Fig. 1. Infected pancreatic pseudocyst compressing the gastric wall.

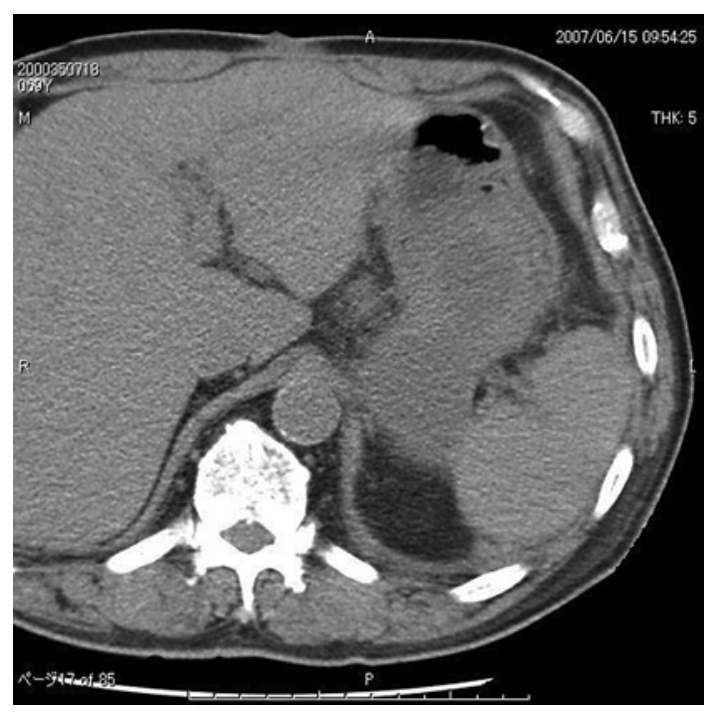

Fig. 2. Lap-Protector was placed around the anterior gastric wall. Thick pus was sucked out. A small incision was made on the posterior gastric wall to reach the abscess wall. Complete anastomosis was performed using a circular stapler.
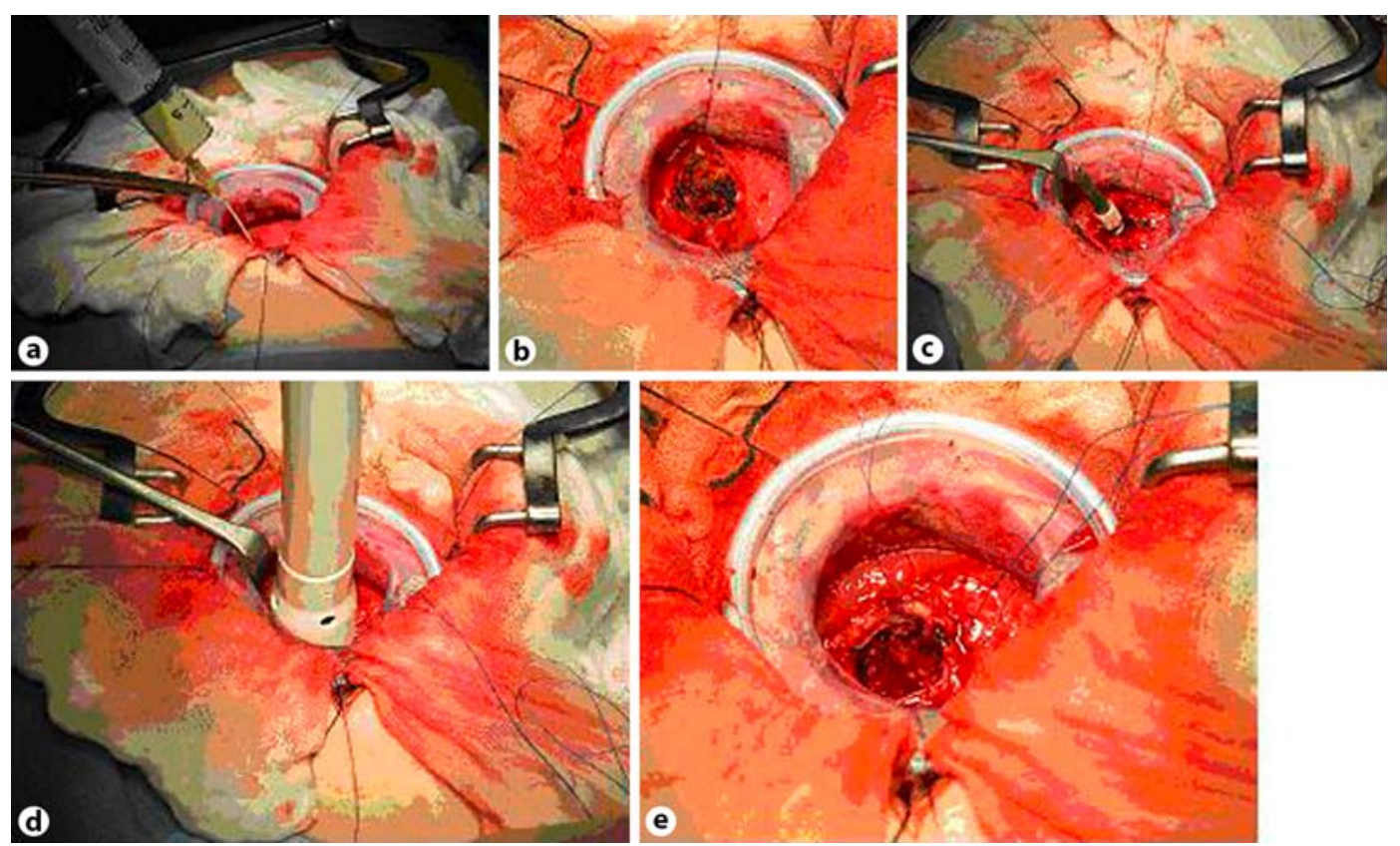


\begin{tabular}{r|l|l|l} 
Case Reports in & $\begin{array}{l}\text { Case Rep Gastroenterol 2010;4:215-219 } \\
\text { D0I: 10.1159/000279763 }\end{array}$ & Published online: July 21, 2010 & $\begin{array}{l}\text { @ 2010 S. Karger AG, Basel } \\
\text { ISSN 1662-0631 } \\
\text { www.karger.com/crg }\end{array}$ \\
\hline
\end{tabular}

Fig. 3. Four days after the operation, upper gastrointestinal examination and CT revealed complete drainage without any leakage.

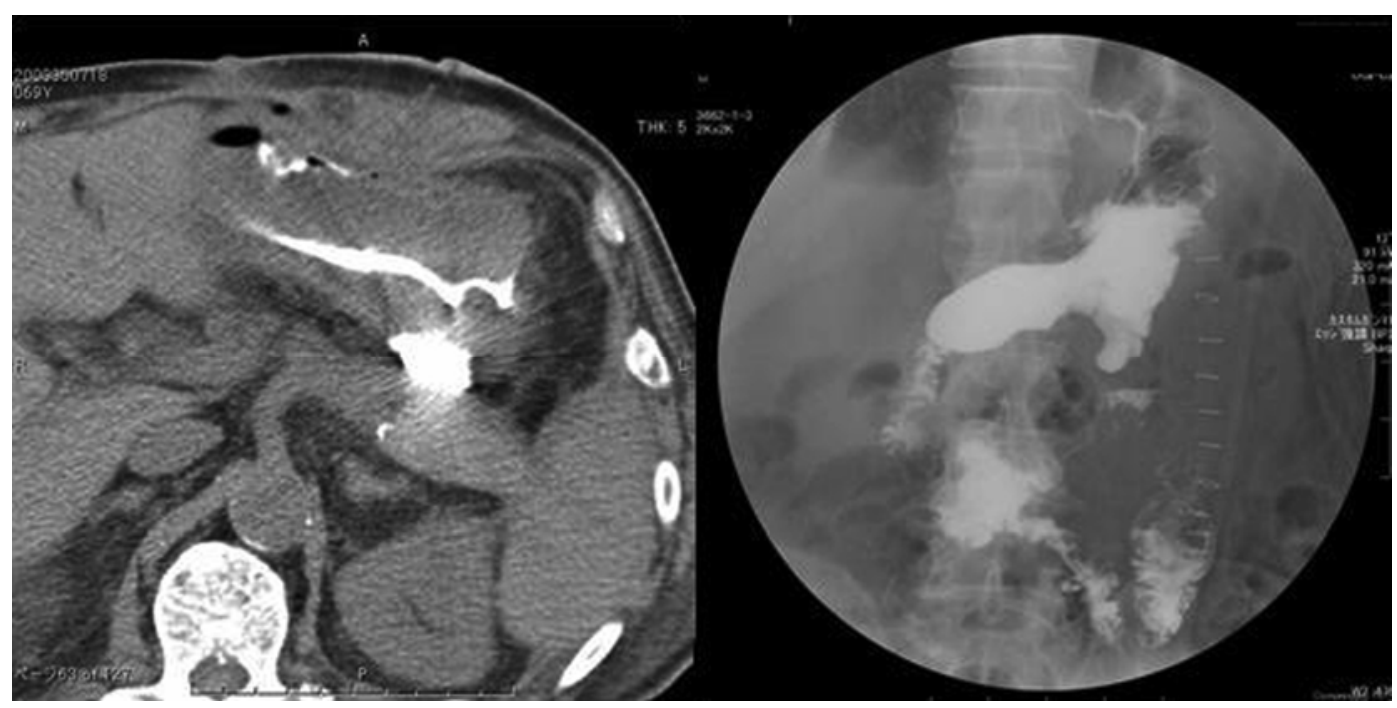

Fig. 4. Two months after discharge, CT revealed no sign of recurrence.

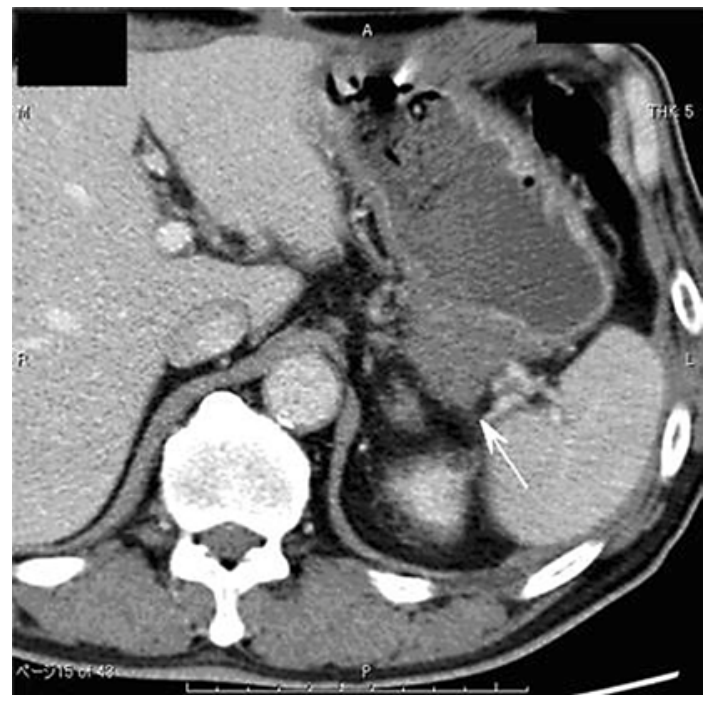




\section{References}

1 Nakagoe T, Sawai T, Tsuji T, Nanashima A, Jibiki M, Yamaguchi H, Yasutake T, Ayabe T, Shimomura K: Minilaparotomy wound edge protector (Lap-Protector): A new device. Surg Today 2001;31:850-852.

-2 Yunoki Y, Takeuchi H, Yasui Y, Tanakaya K, Konaga E, Hamazaki K: Use of disposable stapler in operative cystogastrostomy for pancreatic pseudocyst. Hepatogastroenterology 1999;46:3271-3273.

3 Jedlicka R: Eine neue Operationsmethode der Pankreascysten. Zentralbl Chir 1923;50:132. 